\title{
GENETIC DIVERSITY OF BROWN TROUT POPULATIONS USING MITOCHONDRIAL MARKERS \\ IN RELATIVELY SIMILAR GEOGRAPHICAL AND ECOLOGICAL CONDITIONS - A CARPATHIAN CASE STUDY
}

\author{
Gina-Oana POPA *, Miad KHALAF **, Andreea DUDU ***,

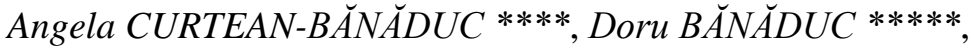 \\ Sergiu GEORGESCU ****** and Marieta COSTACHE *******
}

* University of Bucharest, Faculty of Biology, Department of Biochemistry and Molecular Biology, Splaiul Independenței 91-95, Bucharest, Sector 5, Romania, RO-050095, popa.gina.oana@gmail.com

** University of Bucharest, Faculty of Biology, Department of Biochemistry and Molecular Biology, Splaiul Independenţei 91-95, Bucharest, Sector 5, Romania, RO-050095, miad67@yahoo.com

*** University of Bucharest, Faculty of Biology, Department of Biochemistry and Molecular Biology, Splaiul Independenţei 91-95, Bucharest, Sector 5, Romania, RO-050095, tn_andreea@yahoo.com

**** “Lucian Blaga” University of Sibiu, Faculty of Sciences, Department of Ecology and Environment Protection, Sibiu, Romania, RO-550012, ad.banaduc@yahoo.com, angela.banaduc@ulbsibiu.ro

***** "Lucian Blaga" University of Sibiu, Faculty of Sciences, Department of Ecology and Environment Protection, Sibiu, Romania, RO-550012, ad.banaduc@yahoo.com

****** University of Bucharest, Faculty of Biology, Department of Biochemistry and Molecular Biology, Splaiul Independenței 91-95, Bucharest, Romania, RO-050095, georgescu_se@yahoo.com

******* University of Bucharest, Faculty of Biology, Department of Biochemistry and Molecular Biology, Splaiul Independenţei 91-95, Bucharest, Romania, RO-050095, marietacostache@yahoo.com

DOI: 10.2478/trser-2013-0025

KEYWORDS: Făgăraş Mountains, brown trout, D-loop, genetic diversity.

\section{ABSTRACT}

Among the species of salmonids that exist in Romania, the most common is the brown trout (Salmo trutta, morpha fario, Linnaeus, 1758), with a high commercial potential, being used for aquaculture or fishing. Unfortunately, its natural habitat is disrupted by human activities and in order to avoid local extinction of Salmo trutta fario repopulation strategies are being applied. The repopulation activities must be carefully designed and conducted taking into consideration that there is a high risk of hybridization. Our study aims to analyze the genetic diversity of three Romanian brown trout populations found in rivers in the Făgăraş Mountains using mitochondrial markers.

Standard DNA extraction protocol with phenol-chloroform was applied to the biological material represented by small fin fragments sampled from 80 individuals of brown trout, followed by PCR amplification of D-loop control region and Sanger sequencing. Alignment and editing of all the sequences obtained were carried out with Bioedit, the phylogenetic tree construction was performed by Neighbour Joining method implemented in MEGA v5, and intra- and interpopulational diversity was evaluated with DNAsp v5 and MEGA v5.

For the three brown trout populations, 13 haplotypes were identified for N1, 11 for N2 and 10 for N4, with a haplotype diversity greater than 0.8 . The phylogenetic tree topology showed that individuals chosen for this study were placed in the Danubian clade as the other Danubian sequences selected from GenBank.

The study proved that the three Salmo trutta fario populations analyzed were genetically distinct and that in Romania there are still are pure Danubian brown trout populations. 
RÉSUMÉ: La diversité génétique des populations de truites brunes à l'aide de marqueurs mitochondriaux dans des conditions géographiques et écologiques relativement similaires - une étude de cas des Carpates.

Parmi les espèces de salmonidés qui existent en Roumanie, la plus commune est la truite brune (Salmo trutta fario, Linnaeus, 1758) qui possède un grand potentiel commercial, étant utilisées pour l'aquaculture ou la pêche. Malheureusement, son habitat naturel est perturbé par des activités humaines. Dans le but d'éviter l'extinction de la truite, des stratégies de repeuplement sont appliquées. Les activités de repeuplement doivent être soigneusement conçues et réalisées en tenant compte d'un grand risque d'hybridation. Le but de notre étude est l'analyse la diversité génétique de trois populations de truites brunes roumaines qui se trouvent dans les rivières des Monts Fagărăş à l'aide de la région de contrôle de l'ADN mitochondrial. Le protocole standard d'extraction de l'ADN, au phénol-chloroforme, a été appliqué sur les échantillons biologiques représentés par de petits fragments de nageoire appartenant à 80 individus de truite brune, suivie par l'amplification de la région de contrôle D-loop par PCR ainsi que le séquençage par la méthode Sanger. L’alignement de toutes les séquences obtenues a été réalisé avec Bioedit, la construction de l'arbre phylogénétique a été réalisée par la méthode de Neighbor Joining (logiciel MEGA v5) et la diversité intra- et interpopulationnel a été évaluée avec DNAsp v.5 et MEGAv.5.

Pour les trois populations de truites brunes, 13 haplotypes ont été identifiés pour N1, 11 pour N2, et 10 pour N4, avec une diversité d’haplotypes supérieur à 0,8. La topologie de l'arbre phylogénétique a montré que les truites choisies pour cette étude ont été placées dans le clade danubien, comme les autres séquences du Danube choisis dans GenBank.

Cette étude a prouvé que les trois populations de Salmo trutta fario analysées sont génétiquement distinctes et qu'en Roumanie, il existe toujours des populations de truite brune pures danubiennes.

REZUMAT: Analiza diversităţii genetice cu ajutorul markerilor mitocondriali, a unor populaţii de păstrav comun aflate în condiţii geografice şi ecologice relativ similare în Munţii Carpaţi.

Păstrăvul comun reprezintă una dintre speciile de Salmonidae din România, cu o importanţă comercială deosebită, utilizat în domeniul acvaculturii şi pentru pescuit sportiv. Din nefericire, influenţa antropică se resimte şi în habitatul lui Salmo trutta fario, iar pentru a contracara influenţele negative, se încearcă aplicarea de strategii de repopulare. Activitățile de repopulare trebuie să fie realizate şi desfăşurate cu atenţie, luând în considerare faptul că există un risc ridicat de hibridizare. În cadrul acestui studiu, am avut în vedere analiza diversităţii genetice a trei populaţii de păstrăv comun din regiunea nordică a Munţilor Făgăraş, folosind markeri mitocondriali.

Extracţia de ADN a fost realizată din mici fragmente de înotătoare, provenite de la 80 de indivizi, urmând protocolul standard de extracţie cu fenol-cloroform, urmată de amplificare prin PCR a regiunii mitocondriale D-loop şi secvenţiere după metoda Sanger. Alinierea şi editarea secvenţelor obţinute a fost realizată cu programul BioEdit, iar arborele filogenetic a fost construit prin metoda Neighbour Joining din cadrul programului MEGA v.5. Diversitatea inter- şi intrapopulaţională a fost evaluată cu programele DNAsp v.5 şi MEGA v.5.

Pentru cele trei populaţii analizate, am observat că există 13 haplotipuri în cadrul populaţiei N1, 11 în populaţia N2 şi 10 în populaţia N4, cu o diversitate haplotipică mai mare de 0,8. Topologia arborelui filogenetic a sugerat că indivizii analizaţi au fost grupaţi în clada danubiană, alături de alte secvenţe aparţinând liniei danubiene utilizate la construcţia dendrogramei. 
Acest studiu a demonstrat ca cele trei populații de Salmo trutta fario analizate sunt distincte din punct de vedere genetic şi că în România încă există populații pure de păstrăv comun danubian.

\section{INTRODUCTION}

Among the Salmonidae species that exist in the Romanian national territory, Salmo trutta fario Linnaeus, 1758, Salmo trutta lacustris Linnaeus 1758, Salmo trutta labrax Pallas 1811, Salmo gairdneri irideus Gibbons 1855, Salvelinus fontinalis fontinalis (Mitchil) 1815, Hucho hucho (Linnaeus) 1758, (Bănărescu, 1964; Bănărescu and Bănăduc, 2007), the most common and also the most important from economic point of view is the brown trout (Salmo trutta, morpha fario, Linnaeus, 1758). Representatives of this species are found in alpine lakes from Făgăraş, Parâng and Retezat Mountains, and almost all mountain springs from Romania. Salmo trutta fario is known as a rapacious fish that prefers to ambush its prey in various locations such as rocks, waterfalls or fallen trees (Georgescu et al., 2011), eating insects and larvae. It reaches $25-50 \mathrm{~cm}$ in length and $0.2-5 \mathrm{~kg}$ in weight, and has its reproduction period in late autumn (Bănărescu, 1964).

The brown trout has great commercial potential, its meat being well appreciated, and often it is used for rising in aquaculture conditions. Particularly, in Romania, a great interest in fish farming of brown trout has been manifested since 1890 (Georgescu et al., 2011).

Because of its wide geographical distribution, which runs from Norway to eastern Russia and from Iceland to the tributaries of the Aral Sea, the brown trout shows great diversity concerning phenotypic characteristics (Bernatchez et al., 1992). By using molecular markers, especially the mitochondrial control region D-loop, it was shown that in Europe there are five main lineages of Salmo trutta: Atlantic, Danubian, Marmoratus, Mediterranean and Adriatic (Bernatchez et al., 2001). The D-loop control region is a non-coding region, located between the genes for tRNA $^{\text {Pro }}$ and tRNA ${ }^{\text {Phe }}$, that contains the initiation signals for mitochondrial genome replication (Shadel et al., 1997). Other studies were focused on using RFLP technique to study the genetic differentiation of Salmonids (Maric et al., 2006; Dudu et al., 2010; Apostolidis et al., 1996) or on 16S and 12S rRNA genes sequences to study the phylogenetic classification of Romanian salmonid species (Dudu et al., 2010). The mitochondrial genome has some characteristics that make it useful in phylogenetic and populational studies: fast evolution rate, higher mutation rate than the nuclear genome, maternal heritage - useful for hybrid identification studies - and relatively compact structure.

Unfortunately, the brown trout's natural habitat is disrupted by a series of human activities such as excessive fishing, river dams and hydropower plants construction on main mountain rivers, garbage disposal and ballast exploitation. In order to avoid endangerment or even local extinction of Salmo trutta fario, repopulation strategies are being applied, frequently with individuals that come from aquaculture. Uncontrolled population restocking with non-native brown trout individuals often used in aquaculture might lead to hybrid formation, affecting the genetic diversity of natural Salmo trutta populations (Guyomard, 1989). Furthermore, the classification of resulting hybrids is difficult to achieve based exclusively on morphology, and a genetic analysis is recommended (Boaru, 2008). 
Although in Romania Salmo trutta fario's morphological characteristics are widely described (Bănărescu, 1964; Bănărescu and Bănăduc, 2007), studies concerning the genetic diversity of Romanian brown trout are rare. Until now, there have been no complete studies about its genetic characteristics and this could affect the future potential repopulation programmes that in the past have not taken a systematic approach in this respect.

Our preliminary study aims to analyze the genetic diversity of three Romanian brown trout populations from rivers in the Făgăraş Mountains area using the D-loop control region as a mitochondrial marker.

\section{MATERIAL AND METHODS}

DNA extraction

The biological samples were represented by small anal fin fragments from 80 individuals belonging to three natural populations from the Northern side of the Făgăraş Mountains, tagged as N1, N2 and N4. The DNA extraction was done using standard phenol-chloroform protocol (Taggart, 1991) with minor modifications and elution in purified water.

\section{PCR optimization and amplification}

The amplification of the entire D-loop region was done using the primers forward 5'CCCAAAGCTAAAATTCTAAAT3' and reverse 5'CCCAAAGCTAAAATTCTAAAT3'. Initially, we optimized the PCR reaction conditions by varying the annealing temperature between 46 and $60^{\circ} \mathrm{C}$. The PCR program that we use for amplification of $1012 \mathrm{bp}$ mitochondrial region of D-loop was as follows: denaturation at $95^{\circ} \mathrm{C}$ for ten minutes, 35 cycles of denaturation at $95^{\circ} \mathrm{C}$ for 30 seconds, annealing at $52^{\circ} \mathrm{C}$ and extension at $72^{\circ} \mathrm{C}$ for one minute and final extension at $72^{\circ} \mathrm{C}$ for ten minutes. The PCR reactions were carried out on GeneAmp 9700 PCR System (AppliedBiosystems) with a final volume of $25 \mu$ l that contained 1X PCR Buffer, $1.5 \mathrm{mM}$ of MgCl2, $0.8 \mathrm{mM}$ of dNTPs, two pmol/ $\mu 1$ of each primer, one unit of AmpliTaq Gold DNA polymerase, nuclease free water and $50 \mathrm{ng}$ of DNA template. The PCR products were analyzed by electrophoresis on $2 \%$ agarose gel in TAE $1 \mathrm{X}$.

\section{PCR products purification and sequencing}

The purification of PCR products was carried out with Wizard SVGel and PCR CleanUp System (Promega), followed by Sanger sequencing using Big Dye Terminator v3.1 kit (Applied Biosystems) and the sequencing products were loaded on the 3130 Genetic Analyzer (Applied Biosystems) after a previous purification with BigDye XTerminator ${ }^{\circledR}$ Purification Kit (Applied Biosystems).

\section{Sequence alignment}

The sequences were edited, compared and aligned to other brown trout D-loop sequences downloaded from Gene Bank (accession number GQ284837) and truncated to 903bp by using Bioedit (Hall, 1999).

\section{Data analysis}

In the phylogenetic analysis, besides our sequences, we used control region sequences from GenBank database that belong to four different lineages: Atlantic, Danubian, Mediterranean and Adriatic (Tab. 1). The phylogenetic tree construction was performed by Neighbor Joining method implemented in MEGA v5 and Salmo salar (GenBank accession number U12143) was selected as outgroup. The intra- and interpopulational diversity was evaluated with DNAsp v5 (Librado et al., 2009) and MEGAv5 (Tamura et al., 2011). 
Table 1: The accesion number and lineage of each external control region sequence used for phylogenetic analysis.

\begin{tabular}{|c|c|}
\hline \multirow{2}{*}{ Lineage } & $\begin{array}{c}\text { Accesion number } \\
\text { (GenBank) }\end{array}$ \\
\hline \multirow{4}{*}{ Adriatic } & AY836330 \\
\cline { 2 - 2 } & DQ381566 \\
\cline { 2 - 2 } & AY836331 \\
\cline { 2 - 2 } & DQ381567 \\
\hline \multirow{4}{*}{ Atlantic } & AF273086 \\
\cline { 2 - 2 } & AF274574 \\
\cline { 2 - 2 } & AY185578 \\
\cline { 2 - 2 } & AF273087 \\
\hline \multirow{4}{*}{ Mediterranean } & AY185577 \\
\cline { 2 - 2 } & AY836361 \\
\cline { 2 - 2 } & AY836364 \\
\cline { 2 - 2 } & AY836362 \\
\hline & AY836363 \\
\hline Danubian & AY185571 \\
\cline { 2 - 2 } & GQ284837 \\
\hline
\end{tabular}

\section{RESULTS AND DISCUSSION}

All 80 complete D-loop sequences of 1012 bp obtained from Salmo trutta fario were aligned with a similar sequence from GenBank and after truncation to $903 \mathrm{bp}$ they were used for analysis with DNAsp, v5. We aimed to explore the inter- and intrapopulational diversity and discovered that the number of polymorphic sites was as follows: 9 for the N1 population, 24 for the N2 population and 14 for the N4 population (Fig. 1), most of them being transition type polymorphisms. The haplotype diversity for each of all three populations was relatively high, with values $>0.8$ (Tab. 2). These values suggest that there is a significant level of genetic variation within all three analyzed populations. For the three Salmo trutta fario populations, 13 haplotypes were identified for N1, 11 for N2 and 10 for N4 (Tab. 2).

Table 2: The analysis of three brown trout populations concerning the number of polymorphic sites, number of haplotypes and haplotype diversity by using DNAsp v5.

\begin{tabular}{|c|c|c|c|}
\hline Population & $\begin{array}{c}\text { Number of } \\
\text { polymorphic/indel/missing sites }\end{array}$ & $\begin{array}{c}\text { Number of } \\
\text { haplotypes }\end{array}$ & $\begin{array}{c}\text { Hd } \\
\text { (haplotype diversty) }\end{array}$ \\
\hline N1 & 9 & 13 & 0.865 \\
\hline N2 & 24 & 11 & 0.826 \\
\hline N4 & 14 & 10 & 0.852 \\
\hline
\end{tabular}

The genetic differentiation degree between the three populations was also evaluated with DNAsp and by Wrigth statistics (Fig. 1). We observed that the highest values $(>0.25)$ both for Fst and Gammast indices were obtained between the N1 and N2 populations (Fst = 0.7 , Gammast $=0.56$ ) and the lowest between the N2 and N4 brown trout populations. The values of the analyzed statistical indices reflect that the populations are genetically distinct and the highest degree of genetic differentiation is between the $\mathrm{N} 1$ and $\mathrm{N} 2$ populations, while the lowest is between N2 and N4. 


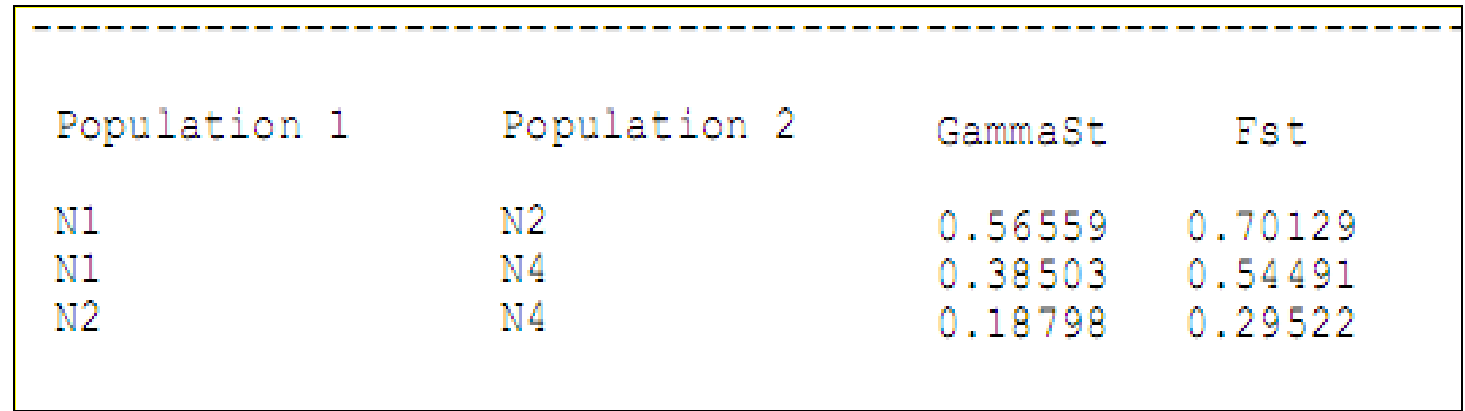

Figure 1: The values of the Wright statistical indices for the three analyzed brown trout populations (N1, N2 and N4) evaluated with DNAsp.

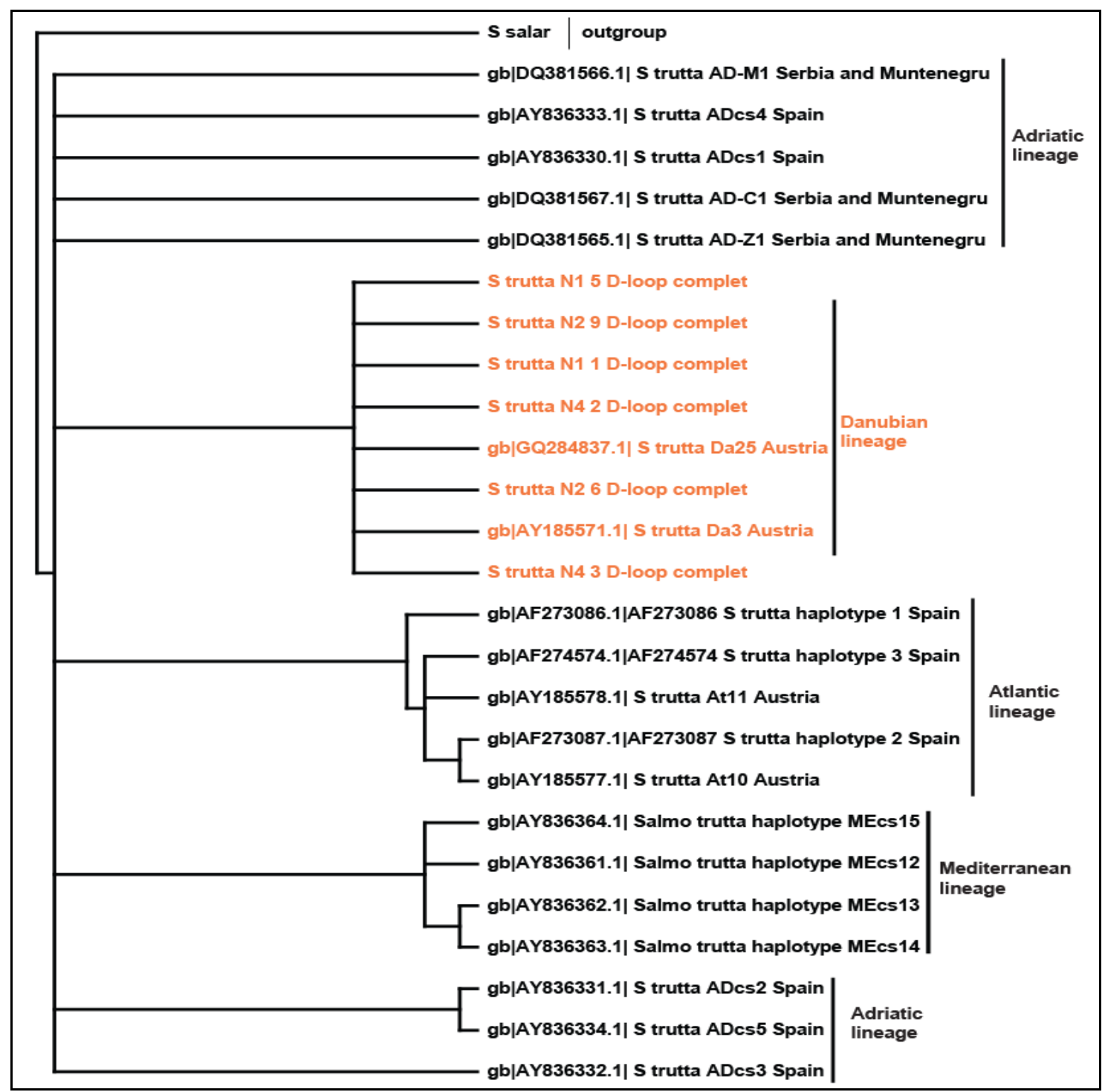

Figure 2: Phylogenetic tree obtained with MEGAv5 (NJ method, bootstrap value 1000 replications) illustrating the relationships between the evolutive lineages of brown trout. 
The phylogenetic tree resulting from analysis with MEGA v.5 contained, besides our Salmo trutta fario sequences, complete D-loop sequences from other European lineages in order to observe the affiliation of analyzed Romanian individuals. The dendrogram topology showed a classification of analyzed sequences in distinct monophiletic groups corresponding to each evolutive lineage, and that the representatives of brown trout from Romania analyzed in this study were placed in the Danubian clade similar to other sequences selected from GenBank and belonging to Danubian lineage (Fig. 2).

In Romania, we expected to find individuals from the Danubian lineage and this was found to be the case, meaning that either restocking programs have not been done yet or, if they have, the individuals involved were selected properly.

The genetic diversity of Romanian brown trout concerns us due to ongoing construction of hydropower plants on several mountain rivers in the northern side of the Făgăraş Mountains. Also, in the area, there are several trout farms from which it is possible for non-indigenous individuals to escape, leading to hybrid formation. All of these anthropic activities might severely degrade the aquatic ecosystems.

Our next steps are to evaluate the genetic diversity in a higher number of populations of Salmo trutta fario from other Romanian mountain regions in order to ensure a better view upon the actual state of brown trout in our country.

\section{CONCLUSIONS}

To conclude, it was proven that the three analyzed Salmo trutta fario populations were genetically distinct and that in Romania there still are pure Danubian brown trout populations. This study is a first step in the molecular characterization of Salmo trutta fario from Romania using mitochondrial DNA markers and could provide precious information in future management strategies.

\section{REFERENCES}

1. Apostolidis A. P., Karakousis Y. and Triantaphyllidis C., 1996 - Genetic differentiation and phylogenetic relationships among Greek Salmo trutta L. (brown trout) populations as revealed by RFLP analysis of PCR amplified mitochondrial DNA segments, Heredity, 77, 608-618.

2. Bănărescu P., 1964 - Fauna Republicii Populare Române, Piscies-Osteichtyes (Peşti ganoizi şi osoşi), Edit. Academiei R. P. R., Bucureşti, XIII, 263-264. (in Romanian)

3. Bănărescu P. and Bănăduc D., 2007 - Habitats Directive (92/43/EEC) fish species (Osteichthyes) on the Romanian territory, Acta Ichtiologica Romanica, II, 43-78.

4. Bernatchez L., 2001 - The evolutionary history of brown trout (Salmo trutta L.) inferred from phylogeographic, nested clade, and mismatch analyses of mitochondrial DNA variation, Evolution, 55, 2, 351-379.

5. Bernatchez L., Guyomard R. and Bonhomme F., 1992 - DNA sequence variation of the mitochondrial control region among geographically and morphologically remote European brown trout Salmo trutta populations, Molecular Ecology, 1, 161-173.

6. Boaru A., 2008 - Breeding and exploitation of native salmonids species with a view to diversity the fish production and preserve the biodiversity, Lucrări Ştiinţifice Zootehnie şi Biotehnologii, Timişoara, 41, 2, 18-22.

7. Dudu A., Georgescu S. E., Dinischiotu A. and Costache M., 2010 - PCR-RFLP method to identify fish species of economic importance, Archiva Zootechnica, 13, 1, 53-59.

8. Dudu A., Popa O., Georgescu S. E., Dinischiotu A. and Costache M., 2010 - Molecular analysis of Romanian salmonid species based on 16srRNA and 12s rRNA sequences, Archiva Zootechnica, 13, 3, 30-40. 
9. Duftner N., Weiss S., Medgyesy N. and Dturmbauer C., 2003 - Enhanced phylogeographic information about Austrian brown trout populations derived from complete mitochondrial control region sequences, Journal of Fish Biology, 62, 427-435.

10. Georgescu S. E., Dudu A., Suciu R., Vîrban I., Ionescu O. and Costache M., 2011 - Evaluarea şi caracterizarea genetică a salmonidelor din România, Bucureşti, 1-142. (in Romanian)

11. Guyomard R., 1989 - Diversité génétique de la truite commune, Bulletin Francais de la Peche et de la Pisciculture, 314, 118-135. (in French)

12. Hall T. A., 1999 - BioEdit: a user-friendly biological sequence alignment editor and analysis program for Windows 95/98/NT, Nucleic Acids Symposium Series, 41, 95-98.

13. Librado P. and Rozas J., 2009 - DNAsp v5: A software for comprehensive analysis of DNA polymorphism data, Bioinformatics, 25, 1451-1452.

14. Maric S., Snoj A., Nikolic V. and Simonovici P., 2006 - Genetic differentiation of trout (Salmo spp.) populations in Serbia ascertained using RFLP technique on PCR amplified control region of mitochondrial DNA, Beograd, Acta Veterinaria, 56, 423-430.

15. Maric S., Susnik S., Simonovici P. and Snoj A., 2006 - Phylogeographic study of brown trout from Serbia, based on mitochondrial DNA control region analysis, Genetique, Selection, Evolution, 38, 411-430.

16. Nelson J., 2006 - Fishes of the world, Wiley, New York, 835-838.

17. Shadel G. S. and Clayton D. A., 1997 - Mitochondrial DNA maintenance in vertebrates, Annual Review of Biochemistry, 66, 409-35

18. Taggart J. B., Hynes R. A., Prodohl P. A. and Ferguson A., 1991 - A simplified protocol for routine total DNA isolation from salmonid fishes, Journal of Fish Biology, 40, 6, 963-965.

19. Tamura K., Peterson D., Stecher G., Nei M. and Kumar S., 2011 - MEGA5: Molecular Evolutionary Genetics Analysis using Maximum Likelihood, Evolutionary Distance, and Maximum Parsimony Methods, Molecular Biology and Evolution, 28, 2731-2739. 